\title{
Sustainable agriculture for the steppe birds' conservation: land stewardships as a cornerstone
}

\section{Opinion}

Support farmers through land stewardship agreements in the implementation of farming measures that allow them to improve the profitability of their farms, to have access to Rural Development funds or to join any initiative of differentiated marketing, is a guaranty to make a step forward in the steppe birds conservation in Castile-La Mancha, Spain.

Land stewardship is a set of strategies and instruments aimed at involving the owners and users of the territory in the conservation and proper use of the natural, cultural and landscape values and resources. It promotes agreements and collaboration mechanisms among owners, stewardship bodies and other public and private agents. Land stewardship bodies are public or private not-for-profit organizations. Land stewardship is embodied in voluntary agreements among owners and land managers and territory stewardship bodies to maintain or recover the natural medium and the landscape. Fundación Global Nature (FGN) is a Spanish private non-for-profit foundation dedicated to nature protection. Its work is based on technical expertise, ethical commitment and innovation. Since the beginning of its foundation, land stewardships have been one of its strategies to nature conservation. In Castile-La Mancha FGN is developing The "Steppes of La Mancha" LIFE project. This initiative is intended to slow down the fall in the populations of steppe birds in collaboration with farmers in four of the main Special Bird Protection Areas of Castile-La Mancha included within the Nature 2000 network. This initiative takes place between 2016 and 2019 in 57 municipalities of four Special Bird Protection Areas and Special Conservation Areas in La Mancha District. It is co-financed by the European Union's LIFE programme and its partners include Fundación Global Nature and the Regional Government of Castilla La Mancha. The main project's objective is the conservation of populations of steppe birds included in article 4 of the Directive 2009/147/EC, referred to in Annex I: Otis tarda, Tetrax tetrax, Circus pygargus, Pterocles alchata, Pterocles orientalis, Chersophilus duponti, Circus cyaneus, Falco naumanni, Burhinus oedicnemus and Grus.

To reach the goals of the Steppes of La Mancha LIFE project, a voluntary land stewardship network has been set up for private land, mainly held by crop and cattle farmers with farms in areas of interest for steppe birds on which action plans are applied to each farm. Nowadays, more than 3.000 ha are included in the land stewardship and 53 farmer are involved in the implementation of agroenviromental measures (optimization of the nitrogen fertilization, reduction of pesticides and Crop rotation, and so on) to reduce not only the impact in the steppe bird's habitat but also to be competitive with its products and reduce cost of crop implementation.

The Castile-La Mancha steppe is in fact a pseudo steppe, a very valuable ecosystem created by the transformation of the landscape through the agrarian activity since Neolithic age. At the same time, this land transformation has contributed to the adaptation of several bird species to an agricultural mosaic that now, is needed to its survivor

\author{
Volume 2 Issue 5 - 2017
}

Ernesto Aguirre-Ruiz
Foundation Global Nature, Spain

Correspondence: Ernesto Aguirre-Ruiz, Foundation Global Nature, Calle Real 48, Local A. Las Rozas, Madrid 2823I, Spain, Email eaguirre@fundacionglobalnature.org

Received: November 22, 2017 | Published: December 0I, 2017

The landscape is characterized by an ensemble of cultivated areas with some areas of fallow land and pastures in between, with small enclaves of evergreen holm oaks, kermes oaks or diverse scrub land (mainly gorse). All these areas, cultivated since ancient times, has been dominated, predominantly, with unirrigated cereals, leguminous and some vineyards and olives tree. Due there are currently great challenges in this sector to halt biodiversity loss caused by processes such as intensification and the simplification of farming techniques, the implementation of agroenviromental measures in crops supported by a periodically monitoring (bird census, ecological infrastructure evaluation, so on), is needed.

The steppe birds, such as Great bustard is characteristic of wide open spaces, and the herbaceous croplands of SPAs in Nature 2000 network, offers this habitat. But the only way to conserve these steppe birds' habitat (also, these croplands) is through the support of the farmers that works every day to maintain their families. In this way, the Common Agricultural Policy (CAP) which is the agricultural policy of the European Union have a tool to supports action to adopt and maintain farming practices that help meet environment and climate goals. The 'Greening', since 2013 CAP reform, makes the direct payments system more environment-friendly (30\% of EU countries' direct payment budgets). Nevertheless, the consumers are also part of the steppe birds' conservation. A consumer has to be informed about where the products come from, how has been cultivated and at the same time, a responsible consumer has to claim for products that helps to biodiversity conservation. For example, if a lentil is produced not only as organic product but also comes from a plot where the biological control is implemented with the support of a buffer strip of native plants next to the crop, then this product is sustainable as well improve the habitat of steppe birds. The steppe birds' conservation is a task that required the involved of the whole society, not only a commitment between land owners and stewardship bodies but also need that food processors, consumers and so on (a bigger network), invest efforts to ask for products involved in conservation projects in the own crop area, and that means crops where the agroenvironmental measures implementation is a normal style of management (Figure 1). 


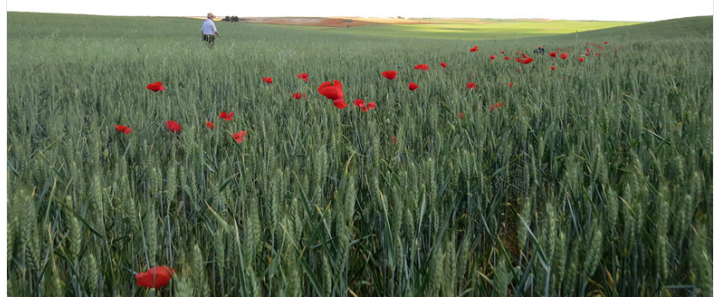

\section{Acknowledgements}

a. European Commission - Environment - LIFE Programme

b. The Spanish Ministry of Agriculture and Fish, Environment and Food

c. Fundación Biodiversidad. España.

\section{Conflict of interest}

The author declares no conflict of interest. 